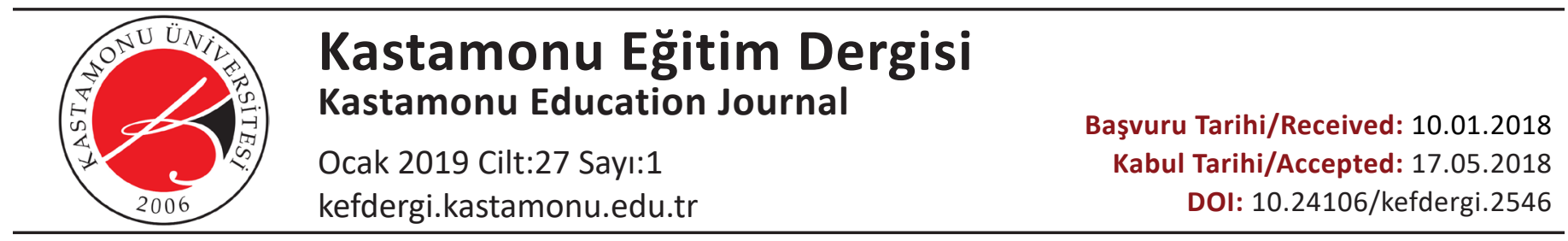

\title{
Ortaokul Öğretmenlerinin Merkezi Sınavlara Yönelik Görüşleri'
} Middle School Teachers' Views about High-Stakes Tests'

\author{
Öz \\ Serkan BULDUR ${ }^{2}$, Mustafa ACAR ${ }^{3}$
}

Bu araştırmanın amacı ortaokul öğretmenlerinin merkezi sınavlar hakkındaki görüşlerini belirlemeye yönelik olarak geliştirilen bir ölçeği Türkçe'ye uyarlayarak ulusal alan yazına kazandırmak ve aynı zamanda öğretmenlerin merkezi sınavlara ilişkin görüşlerinde cinsiyet, mesleki kıdem ve branş değişkenleri açısından farklılık olup olmadığını incelemektir. Bu kapsamda Genç (2005) tarafindan geliştirilen “Merkezi Sınavlara Yönelik Görüşler Ölçeği” Türkçe 'ye uyarlanarak, geçerlik ve güvenirlik çalışması yapılmıştır. Araştırmanın çalışma grubunu bir ilin merkez ilçe ortaokullarında görev yapan 356 ortaokul branş öğretmeni oluşturmaktadır. Çalışma sonucunda, ölçeğin orijinal halindeki iki faktörlü yapı ile Türkçe formundaki ve Türk öğretmenler örneklemindeki yapı, uyumlu olarak tespit edilmiştir. Ölçek orijinal halinde olduğu gibi 12 maddeden ve iki faktörden oluşmaktadır.

Anahtar Kelimeler: Merkezi sınavlar, ortaokul öğretmeni, cinsiyet, branş, kıdem

\begin{abstract}
The aim of this study is to contribute to the national literature by adapting a scale designed for determining the views of teachers on the high-stakes tests and investigate whether teachers' views on high-stakes tests differ by their gender, year of experience and course they teach. For this purpose, the "General View about High-Stakes Testing Scale" developed by Genc (2005) is adapted to Turkish by conducting validity and reliability analyses. The study group consisted of 356 middle school teachers working at schools in the central district of a city. From the result of the study, two factorial structure of the original scale was found to be preserved in the Turkish version of the scale and for Turkish teachers sample. Similar to its original version, the Turkish version of the scale is concluded to consists of 12 items under two factors.
\end{abstract}

Keywords: High-stakes test, secondary school teacher, gender, branch, year of experience

1. Bu çalışma "Fen bilimleri öğretmenlerinin ölçme ve değerlendirme uygulamaları ve uygulamalarını etkileyen faktörler" başlıklı yüksek lisans tezinin bir bölümünden üretilmiştir ve Cumhuriyet Üniversitesi Bilimsel Araştırma Projeleri (CÜBAP) tarafindan EGT 046 proje numarası ile desteklenmiştir.

2. Sivas Cumhuriyet Üniversitesi, Eğitim Fakültesi, Matematik ve Fen Bilimleri Eğitimi Bölümü, Sivas, Türkiye;https://orcid.org/0000-0002-0733-4287

3. Sivas Cumhuriyet Üniversitesi, Eğitim Bilimleri Enstitüsü, Sivas, Türkiye;https://orcid.org/0000-0001-8814-8891

Atıf / Citation: Buldur, S., \& Acar, M. (2019). Ortaokul öğretmenlerinin merkezi sınavlara yönelik görüşleri. Kastamonu Education Journal, 27(1), 319-330. doi:10.24106/kefdergi.2543 


\section{Extended Abstract}

High-stakes tests can be defined as a determinant important factor on making significant decision related to educational period such as placement of students in some programs and deciding their educational progress, determining teacher's performances and school success rates (Greene, 2011). High-stake tests have an important effect also in terms of educational process outside their effect on student's educational life. Such effects of high-stake tests directly effects all the stakeholders of education, especially students, teachers, parents and school managers (Jones ve Egley, 2004). This effect of high-stake tests related to education on many stakeholders has made existence of these exams on education literature a contradictive topic. As a result of several studies, high-stake tests were found to have positive effects such as providing a standard in assessment and evaluation (Afflerbach, 2004; Genç, 2005), increasing motivations of students in terms of studying (Elmore, 2004; Herman, 2004; Kahraman, 2014),, showing the successes of students according to the society they are in and comparing their successes (Jones, Jones ve Hargrove, 2003; Pedulla vd. 2003). However, contrary to these, in some studies, high-stake tests were stated to have adverse effects due to reasons such as causing pressure and stress for students (Buyruk, 2014; Genç, 2005; Dawson, 2012), teachers and families, being an obstacle in front of implementation of education program, promoting only test-oriented teaching (Moses ve Nanna, 2007), increasing the workload of teachers and decreasing the anxiety and motivation of students (Abrams vd. 2003;Greene, 2011; Şad ve Şahiner, 2016). In the lights of these, purpose of this study is to gain a scale towards determining views of secondary school teachers into the literature and to investigate if there is any different in views of teachers on high-stake tests in terms of gender, year of experience and branch variables. Within this context, a validity and reliability study was conducted by adapting "General View About High-Stakes Testing Scale" developed Genc (2005) into Turkish. The study group is composed of 356 secondary school teachers working in secondary schools in Central district of a province. For adaptation study, Turkish form of scale was prepared based on expert opinions. Later, the original Turkish form and scale was applied to 31 prospective teacher studying in English Language Teaching Department and the relation level between score obtained from Turkish and English forms was determined by calculating the Pearson Moment Correlation Coefficient. Confirmatory factor analysis (CFA) techniques were used to determine the validity of the scale after completion of the study relating language validity. Cronbach $\alpha$ internal reliability coefficients were calculated to determine the reliability of the items included in the scale. In order to determine the distinctiveness of the items, item-total correlations were calculated and the difference between the item scores of the upper $27 \%$ and lower $27 \%(n=96)$ groups determined by the total score was determined by t-test. The multivariate test, MANOVA (multivariate ANOVA), was used to examine whether the participants' opinions regarding the high-stake tests varied according to gender, branch and years of experience. In order to determine the language validity of the scale, the correlation coefficient between Turkish and English forms, which were applied each one week to 31 students studying in English Language Teaching Department, was determined as .97. As a result of the construct validity of the scale, it was seen that there was no item showing overlapping in the scale, and when the slope-accumulation graph was examined, the eigenvalue of the scale was gathered under 2 factors which are higher than 1 . The total variance ratio explained by these two factors is $50.41 \%$. It is seen that some conformity indices are good (GFI, CFI, $\mathrm{NNFI}, \mathrm{SRMR}$,) and some are moderate ( $\chi 2$ / sd) when the compliance indices obtained from study findings in CFA for structure validity are compared with accepted values in field writing. The coefficient of the first factor (positive views) of the scale was .79 and the coefficient of the second factor (negative views) was calculated to be .75 in the calculated Cronbach $\alpha$ internal reliability coefficient scale. It was determined that item-total correlations of the scale change between .38 and .64 in the results of the item analysis conducted in order to determine the distinctiveness levels of the items in the scale. The results of the t-test between item mean scores of the upper $27 \%$ and lower $27 \%$ groups show that the differences are significant for all items. As a result, the two factorial structure in its original state of scale and the structure in the Turkish form and in the Turkish population were found to be harmonious. The scale consists of 12 items and two factors as they are in the original version. The first factor with 7 items is called "Positive View About High-Stakes Testing Scale" and the second factor with 5 items is called "Negative Views About High-Stakes Testing Scale". According to the pilot study data, there is a significant difference between the teachers' scores on the high-stake tests $(t(355)=14.04 p<.01)$. According to this difference, positive views of teachers on high-stake tests are significantly higher than negative views. The results whether the views of teachers towards high-stake tests are differentiated in terms of independent variables in the study are investigated. According to findings, it was determined that the views scores of teachers on high-stake tests did not differ significantly in terms of gender (Wilks' Lambda=0.99; $F(2,353)=0.80 ; p>.01$ ), branch (Wilks' Lambda=0.69; $F(12,616)=0.98 ; p>.01$ ) and years of experience (Wilks' Lambda $=1.81 ; F(8,684)=0.96 \mathrm{p}>.01$ ). As a result, it was determined that secondary school teachers had both positive and negative views on high stake tests, but that positive views were significantly higher than negative views. In this study, a scale in which teachers 'view on high-stake tests can be determined in general was gained to the national body of literature. This way, use of this scale is suggested in different studies where the views of teachers on high-stake tests will be studied. 


\section{Giriş}

Öğretmenlerin öğretim sürecinde gerçekleştirdikleri değerlendirme uygulamalarını pek çok faktör etkilemektedir. Bu faktörlerden bazıları; değerlendirmeye yönelik inançlar (Calveric, 2010; McWaters, 2001), okul imkânları (Abadiano ve Turner, 2003), zaman (Flowers, Delzell, Browder ve Spooner, 2005; Genç, 2005; Gilligan, 2007; Watt, 2005) ve merkezi sınavlar (Abrams, Pedulla ve Madaus, 2003; Bol, 2004; Hilliard, 2000; Schulz, 2005) olarak sayılabilir. Bu faktörler arasında yer alan merkezi sınavlar aslında sadece öğretmenlerin değerlendirme uygulamalarını değil öğretim süreçlerini de doğrudan etkilemektedir (Dawson, 2012; Moses ve Nanna, 2007; Osborn, 2015; Schulz, 2005). Yapılan pek çok çalışma, merkezi sınavların öğretmenlerin öğretim uygulamalarını etkilediğini ve aynı zamanda öğrencilerin de kaygı, özyeterlik ve motivasyon gibi pek çok duyuşsal özellikleri üzerinde önemli bir etkiye sahip olduğunu ortaya koymaktadır (Abrams vd. 2003; Greene, 2011).

\section{Merkezi Sınavlar}

Merkezi sınavlar, öğrencilerin bazı programlara yerleştirilmeleri ve eğitimsel olarak ilerlemelerine karar verilmesi, öğretmenlerin performanslarının ve okul başarı düzeylerinin belirlenmesi gibi eğitim süreci ile ilgili önemli kararların alınmasında belirleyici olan önemli bir faktör olarak tanımlanabilir (Greene, 2011). Merkezi sınavlarda alınan puanlar kişilerin hayatyyla ilgili firsatları ya da seçeneklerinde de önemli bir etkiye sahiptir (Moses ve Nanna, 2007). Çünkü öğrenciler eğitim hayatları boyunca pek çok merkezi sınava girerler ve buralardan aldıkları sonuçlar onların herhangi bir eğitim kurumuna yerleşme ya da mezun olabilme, ya da çeşitli burslardan veya ödüllerden faydalanma gibi hayatları ile ilgili çok önemli kararları etkilemektedir (Schulz, 2005).

Merkezi sınavlar, öğrencilerin eğitimsel hayatlarına olan etkisinin dışında aslında öğretim süreci açısından da önemli bir etkiye sahiptir. Merkezi sınavların bu etkileri başta öğrenciler, öğretmenler, aileler ve okul yöneticileri olmak üzere eğitimle ilgili bütün paydaşları doğrudan etkilemektedir (Jones ve Egley, 2004; Smyth, 2008). Merkezi sınavların eğitimle ilgili pek çok paydaş üzerindeki bu etkisi, bu sınavların varlığını alanyazında tartışmalı bir konu haline getirmiştir. Bazı araştırmacılar merkezi sınavların ölçme ve değerlendirmede bir standart sağlaması (Afflerbach, 2004; Genç, 2005), öğrencilerin çalışmaya yönelik motivasyonlarını artırması (Elmore, 2004; Herman, 2004; Kahraman, 2014), öğrencilerin içinde bulundukları toplum standartlarına göre başarılarını ortaya koyması ve başarıların karşılaştrıımasını sağlaması (Jones, Jones ve Hargrove, 2003; Pedulla vd. 2003) gibi olumlu etkilere sahip olduğunu ifade etmektedirler. Ancak bunun aksine bazı araştırmacılarda merkezi sınavların, öğrencileri, öğretmenleri ve aileleri baskı altnnda tuttuğu ve strese neden olduğu (Buldur ve Doğan, 2017; Buyruk, 2014; Genç, 2005; Dawson, 2012; Moses ve Nanna, 2007), öğretim programının uygulanmasının önünde engel teşkil ettiği (Jones vd. 2003; McMillan, Myran, ve Workman, 1999; Smyth, 2008) sadece teste yönelik öğretimi teşvik ettiği (Elmore, 2004; Genç, 2005; Herman, 2004), öğretmenlerin iş yükünü arttrdığı (Moses ve Nanna, 2007), öğrencilerde kaygı ve motivasyon düşüklüğüne neden olduğu (Abrams vd. 2003; Greene, 2011; Şad ve Şahiner, 2016) gerekçeleriyle olumsuz etkilere neden olduğunu ifade etmektedirler.

Merkezi sınavlarda elde edilen sonuçlar, öğrencilerin herhangi bir eğitim kurumuna yerleşme ya da mezun olabilme, çeşitli burslardan veya ödüllerden faydalanma ve işe yerleşme gibi hayatları ile ilgili çok önemli kararları doğrudan etkilemektedir (Schulz, 2005). Dolayısıyla merkezi sınavlar öğrencilerin akademik ilerleyişlerinde belirleyici bir role sahip olmakla birlikte aslında bireylerin hayatyla ilgili firsatları ya da seçenekleri üzerinde de önemli bir etkiye sahiptir (Greene, 2011; Moses ve Nanna, 2007).

Merkezi sınavların önemi ve varlığına ilişkin tartşsmaların ötesinde özellikle Türk Milli Eğitim Sistemin açısından bu sınavların var olması gerekliliği açıktı. Çünkü Türkiye'de giderek artan genç nüfus ve buna bağlı olarak eğitime olan talebin artması öğrencilerin farklı kurumlara, programlara ve hatta işe yerleştirilmelerinde ya da diğer bir deyişle kademeler arası geçişlerde merkezi sınavlarla mümkün olmaktadır (Dinç, Dere ve Koluman, 2014). Bu durum merkezi sınavların farklı gerekçelerle eleştiri konusu olmakla birlikte bahsedilen önemli kararların alınması açısından uygulanma zorunluluğunu da beraberinde getirmektedir (Gündoğdu, Kızıltaş ve Çimen, 2010).

\section{Türk Eğitim Sisteminde Merkezi Sınavlar}

Türk Milli Eğitim Sisteminin hemen hemen her kademesinde merkezi sınavlar uygulanmaktadır. Günümüzde ortaokuldan liselere geçişte Liseye Geçiş Sınavı (LGS), ortaöğretimden yükseköğretime geçişte Temel Yeterlilikler Testi (TYT) ve Alan Yeterlilikler Testleri (AYT), devlet memurluğuna atanmada Kamu Personeli Seçme Sınavı (KPSS) gibi pek çok sınav uygulanmaktadır.

Özellikle temel eğitimden ortaöğretime geçişe yönelik yapılan sınavlarda son yıllarda büyük değişiklikler meydana gelmiştir. Bu geçişler 2000'li yılların başında Liselere Giriş Sınavı (LGS), 2004-2008 yılları arasında Ortaöğretim Kurumları Seçme ve Yerleştirme Sınavı (OKS), 2008-2013 yılları arasında Seviye Belirleme Sınavı (SBS) ve 2013 yılından itibaren ise 
TEOG sınavları ile yapılmaktadır. Ancak 2017-2018 eğitim öğretim yılı sonu itibarıyla TEOG uygulamasına da son verilerek Liseye Geçiş Sınavı (LGS) sistemine geçiş yapılmıştır. Geçmiş yıllarda yapılan uygulamalara bakıldığında uygulanan sistem ya da sınavın adının yanı sıra sınav sayısı, uygulama yöntemi, sınav içeriği ve değerlendirme kriterleri gibi birçok alanda değişiklerinde yaşandığı söylenebilir (Dinç ve diğerleri, 2014).

\section{Merkezi Sınavlar ve Öğretmenler}

Merkezi sınavların varlığı her ne kadar doğrudan öğrencileri etkilese de öğretmenlerin öğretim uygulamalarını ve motivasyonlarını da önemli ölçüde etkileyen bir faktördür (Schulz, 2005). Abrams vd. (2003) merkezi sınavların öğretmenlere ilişkin etkilerini dört temel başlık altında incelemişlerdir. Bu başlıklar i) öğretim programının ön gördüğü sınıf içi uygulamalar üzerindeki etkisi, ii) öğrencileri sınavlara hazırlama baskısı, iii) öğretmen ve öğrencilerin motivasyonlarına etkisi, iv) hesap verebilirliğe ilişkin görüşler olarak sıralanmıştır. Bu sınıflamanın paralelinde yapılan pek çok araştrmada merkezi sınavların öğretmenlerin öğretimsel uygulamaları üzerinde önemli etkiye sahip olduğu (Jones vd., 2003; McMillan vd., 1999; Smyth, 2008) hatta bazı durumlarda öğretim programı uygulamalarında kısıtlamaya gidilmesine neden olduğu ifade edilmektedir (Furhman, 2004; Jones vd. 2003). Diğer taraftan bazı araştırmacılarda merkezi sınavların varlığının öğretmenlerin değerlendirme uygulamalarını doğrudan etkilediğini ifade etmişlerdir (Bol, 2004; McWaters, 2001; Sikka, Nath ve Cohen, 2007).

Merkezi sınavların öğretmenlere yönelik etkilerine ilişkin ikinci başlık ise bu sınavların öğrencileri sınava hazırlamak konusunda öğretmenleri baskı altına almasına ilişkindir. Yapılan pek çok çalışma sonucunda öğretmenlerin merkezi sınavların varlığı nedeniyle öğrencilerini devamlı olarak bu sınava hazırladıkları ve "teste yönelik öğretim" yaptıkları ifade edilmiştir (Amrein ve Berliner, 2002; Bol, 2004; Dawson, 2012; Genç, 2005; Pedulla vd. 2003; Smyth, 2008). Aslında bu durum merkezi sınavların öğretmenlere yönelik etkileriyle ilgili üçüncü başlık olan öğretmenlerin motivasyonları ile de doğrudan ilgilidir. Öğretmenler öğrencilerini merkezi sınavlara hazırlamak konusunda kendilerini baskı altında hissettikleri için öğretimlerini sınavlara yönelik planlamakta bu durum hem istedikleri gibi bir öğretim yapamamalarına (Schulz, 2005), hem de onları test çözebilecek öğrenci yetiştirmek gibi bir zorunluluğa itmektedir (Genç, 2005). Bu durumda öğretmenleri stres ve baskı altına sokmakta (Abrams vd. 2003; Moses ve Nanna, 2007; Sikka vd. 2007), motivasyonlarını düşürmekte (Paris ve Urdan, 2000) ve yaratıcılıklarını kısıtlamaktadır (Olsen ve Sexton, 2008; Smyth, 2008). Merkezi sınavların öğretmenlere yönelik etkilerine ilişkin son başlık ise bu sınavların hesap verebilirlik açısından katkıları olduğudur. Bazı araştırmacılar (Afflerbach, 2004; Genç, 2005) merkezi sınavları, ölçme ve değerlendirmede bir standart sağlaması açısından olumlu görmekte ve aynı zamanda bu uygulamanın öğretmenlerin performanslarını değerlendirmekte bir araç olarak kullanabileceğini ifade etmektedirler (Schulz, 2005). Hatta yapılan bazı araştırma sonuçlarına göre öğretmenler, öğrencilerinin merkezi sınavlarda ki başarılarını kendi performansları içinde bir gösterge olarak gördüklerinden dolayı bu sınavların yapılmasının kendi performanslarında da bir artı̧̧ meydana getirebileceğini düşünmektedirler (Şad ve Şahiner, 2016). Bu bağlamda bazı öğretmenler merkezi sınavların varlığını hesap verebilirlik açısından olumlu görmektedirler (Schulz, 2005).

Sonuç olarak ilgili alan yazın merkezi sınavların varlığının öğretmenleri pek çok boyut açısından etkilediğini ortaya koymaktadır. Genç'in (2005) merkezi sınavların öğretimi yönlendirdiği vurgusu aslında bu sınavların özelde öğrenci ve öğretmenleri olmak üzere eğitim sürecinin bütün paydaşlarını önemli ölçüde etkilediğini göstermektedir.

\section{Araştırmanın Önemi ve Amacı}

Merkezi sınavların; öğrenciler, öğretmenler, aileler ve okul yöneticileri olmak üzere eğitimle ilgili bütün paydaşlar üzerindeki önemli etkisinden dolayı bu sınavlar alanyazında pek çok araştırmacı tarafindan üzerinde çalışılan önemli bir olgu olarak göze çarpmaktadır (Jones ve Egley, 2004; Smyth, 2008). Ulusal ve uluslararası alan yazın incelendiğinde özellikle merkezi sınavların öğretmenler üzerindeki etkisinin ve öğretmenlerin bu sınavlara ilişkin görüşlerinin incelendiği pek çok çalışmaya rastlanmaktadır (örn: Abrams vd. 2003; Bol, 2004; Moses ve Nanna, 2007; Sikka vd. 2007). Bu çalışmaların bazılarında (Bol, 2004; Gündoğdu ve diğerleri, 2010; Jones ve Egley, 2004; Osborn, 2015; Pedulla vd. 2003) nicel veri toplama araçları kullanılırken bazılarında (Greene, 2011; Schulz, 2005) ise nitel veri toplama araçları kullanıldığı görülmektedir. Özellikle ulusal alan yazında yapılan çalışmalar genellikle küçük örneklemlerle ve nitel veri toplama araçları kullanılarak yürütülmüştür (Buyruk, 2014; Dinç ve diğerleri, 2014; Kahraman, 2014; Özkan ve Benli-Özdemir, 2014). Bunun yanı sıra büyük örneklemlerle ve nicel veri toplama araçlarının kullanıldığı çalışmalar da mevcuttur (Gündoğdu ve diğerleri, 2010; Şad ve Şahiner, 2016) ancak bu çalışmalarda SBS (Gündoğdu ve diğerleri, 2010) ve TEOG (Şad ve Şahiner, 2016) gibi sadece tek bir sınava ilişkin görüşlerle sınırlı kalmıştır. Bu bağlamda çalışmalarda esas alınan araştırma yönteminden ziyade özellikle ulusal alan yazında yürütülen çalışmalar için daha büyük örneklemlerle yürütülen ve daha genellenebilir sonuçların elde edildiği araştırmalara ihtiyaç duyulduğu açıktır. Diğer taraftan Türk Eğitim Sisteminde uygulanan merkezi sınav türlerinin çok sık değişikliğe uğramasından hareketle öğretmenlerin herhangi bir sınav türüne ilişkin değil de genel olarak merkezi sınavların varlığına ilişkin görüşlerin incelendiği çalışmaların yapılması 
da gereklidir. Sonuç olarak bu çalışmayla ulusal alan yazında görülen bu sınırlılıklar aşılmaya çalışılmış ve ayrıca öğretmenlerin genel olarak merkezi sınavlara ilişkin görüşlerini ortaya koyabilecek bir ölçek Türkçe'ye uyarlanarak ulusal alanyazına kazandırılmıştır.

Bu çalışma ulusal alanyazına bir ölçek kazandırmakla birlikte daha önce yürütülen çalışmalara kıyasla büyük bir örneklem grubu ile çalışılması sayesinde daha genellenebilir sonuçlar elde edilmesi ve daha önceki çalışmalardan farklı olarak öğretmenlerin görüşlerini tek bir sınav açısından incelemekten ziyade genel olarak merkezi sınavlara yönelik görüşlerinin ortaya konulması açısından önemlidir. Son olarak bu çalışmada öğretmenlerin görüşlerinin önemli birçok demografik değişken (cinsiyet, branş ve mesleki kıdem) açısından incelenmesi yoluyla alan yazına yeni bilgiler katması açısından da önemli görünmektedir.

Bahsedilen noktalardan hareketle bu araştırmanın amacı, ortaokul öğretmenlerinin merkezi sınavlara yönelik görüşlerini belirlemeye yönelik bir ölçeği Türkçe’ye uyarlamak yoluyla ulusal alanyazına kazandırmak ve aynı zamanda öğretmenlerin merkezi sınavlara ilişkin görüşlerinde, cinsiyet, mesleki kıdem ve branş değişkenleri açısından farklılık olup olmadığını incelemektir. Bu genel amaç çerçevesinde çalışmanın amaçları aşağıdaki gibi belirlenmiştir.

1. Ortaokul öğretmenlerinin merkezi sınavlara yönelik görüşlerini belirlemeye yönelik olarak Genç (2005) tarafindan geliştirilen ve Türkçe'ye uyarlanan “Merkezi Sınavla Yönelik Görüşler Ölçeği”'nin Türkçe formunun geçerlik ve güvenirlik özelliklerini incelemek,

2. Ölçekten elde edilen pilot çalışma verileri (ölçek uyarlama çalışması kapsamında elde edilen) kullanılarak ortaokul öğretmenlerinin merkezi sınavlara yönelik görüşlerini incelemek;

- Öğretmenlerin merkezi sınavlara yönelik olumlu ve olumsuz görüşleri arasında anlamlı bir farklılık olup olmadığını incelemek

3. Öğretmenlerin merkezi sınavlara yönelik görüşlerinde;

- Cinsiyet,

- Branş ve

- Mesleki kıdem değişkenlerine göre farklılık olup olmadığını incelemektir.

\section{Yöntem}

\section{Çalışma Grubu}

Bu araştırma iki farklı çalışma grubu ile yürütülmüştür. İlk çalışma grubu sadece dil geçerliği uygulaması için belirlenmiştir. İkinci çalışma grubu ise ölçeğin geçerlik ve güvenilirlik özelliklerinin belirlenmesi amacıyla seçilmiştir. Ölçek uyarlama çalışması kapsamında yürütülen dil geçerliliği çalışmasının çalışma grubunu, 2015-2016 eğitim öğretim yııında bir Devlet Üniversitesinin Eğitim Fakültesi İngilizce Öğretmenliği programına kayıtlı 31 öğretmen adayı oluşturmuştur.

Ölçeğin geçerlik ve güvenilirlik özelliklerinin belirlenmesi amacıyla yürütülen pilot uygulamanın çalışma grubunu ise devlet ortaokullarında görev yapan 356 ortaokul branş öğretmeni oluşturmaktadır. Çalışma grubunda yer alan katılımcıların belirlenmesinde kolay ulaşılabilir örnekleme yöntemi esas alınmıştır. Katılımcıların demografik özellikleri Tablo 1 'de verilmiştir.

\section{Tablo 1: Katilımcıların demografik özellikleri}

\begin{tabular}{llcc}
\hline \multirow{2}{*}{ Cinsiyet } & & $\mathrm{n}$ & $\%$ \\
\hline \multirow{3}{*}{ Mesleki } & Erkek & 172 & 48,3 \\
& Kadın & 184 & 51,7 \\
\hline & $1-5$ yıl & 69 & 19,4 \\
& $6-10$ yıl & 99 & 27,8 \\
& $11-15$ yıl & 96 & 27,0 \\
& $16-20$ yıl & 54 & 15,2 \\
Branş & 20 yıl üstü & 30 & 8,4 \\
& Türkçe & 64 & 18,0 \\
& Matematik & 52 & 14,6 \\
& Fen Bilgisi & 48 & 13,5 \\
& Sosyal Bilgiler & 45 & 12,6 \\
& İngilizce & 53 & 14,9 \\
& Din Kültürü ve Ahlak Bilgisi & 30 & 8,4 \\
& Teknoloji Tasarım & 24 & 6,7 \\
\hline
\end{tabular}




\section{Merkezi Sınavlara Yönelik Görüşler Ölçeği (MSYGÖ)}

Öğretmenlerin merkezi sınavlara yönelik görüşlerini belirlemeye yönelik olarak Genç (2005) tarafindan geliştirilen ve 12 maddeden meydana gelen "Merkezi Sınavlara Yönelik Görüşler Ölçeği" beşli likert tipindedir ve iki faktörden oluşmaktadır. İlk faktör merkezi sınavlara ilişkin olumsuz görüşlerin yer aldığı 5 maddeden meydana gelmektedir. ỉkinci faktörü ise merkezi sınavlara ilişsin 7 olumlu madde oluşturmaktadır. Ölçeğin orijinal halinde, faktörlerinin iç tutarlıık katsayıları olumsuz maddeler faktörü için .72 ve olumlu maddeler faktörü için .79 olarak hesaplanmıştr. Ölçeğin yapı geçerliliğin belirlenmesi amacıyla doğrulayıcı faktör analizi yapılmıştır. Analiz sonuçlarına göre elde edilen uyum indeksleri şu şekildedir; ki-kare/serbestlik derecesi ( $\chi 2 / \mathrm{sd}$ ); 2.18, karşılaştırmalı uygunluk indeksi (CFI); .94, standartlaştırılmış ortalama hataların karekökü (SRMR); .05, yaklaşık hataların ortalama karekökü (RMSEA); .06.

\section{iş̧lem}

MSYGÖ'nün Türkçeye uyarlama çalışmalarına başlamadan önce orijinal ölçeğin yazarı Evrim GENÇ ile e-mail yoluyla iletişim kurularak ölçeğin Türkçe'ye uyarlama çalışmaları için izin alınmış ve ortaokul öğretmenleri örnekleminde yürütülecek uyarlama çalışmasının uygunluğuna ilişkin görüşü alınmış ve ölçeğin uyarlama çalışmasına başlanmıştr. Ölçeğin uyarlama çalışması Şekil 1'de görüldüğü gibi Şeker ve Gençdoğan (2006) tarafindan önerilen sekiz adım ile yürütülmüştür.

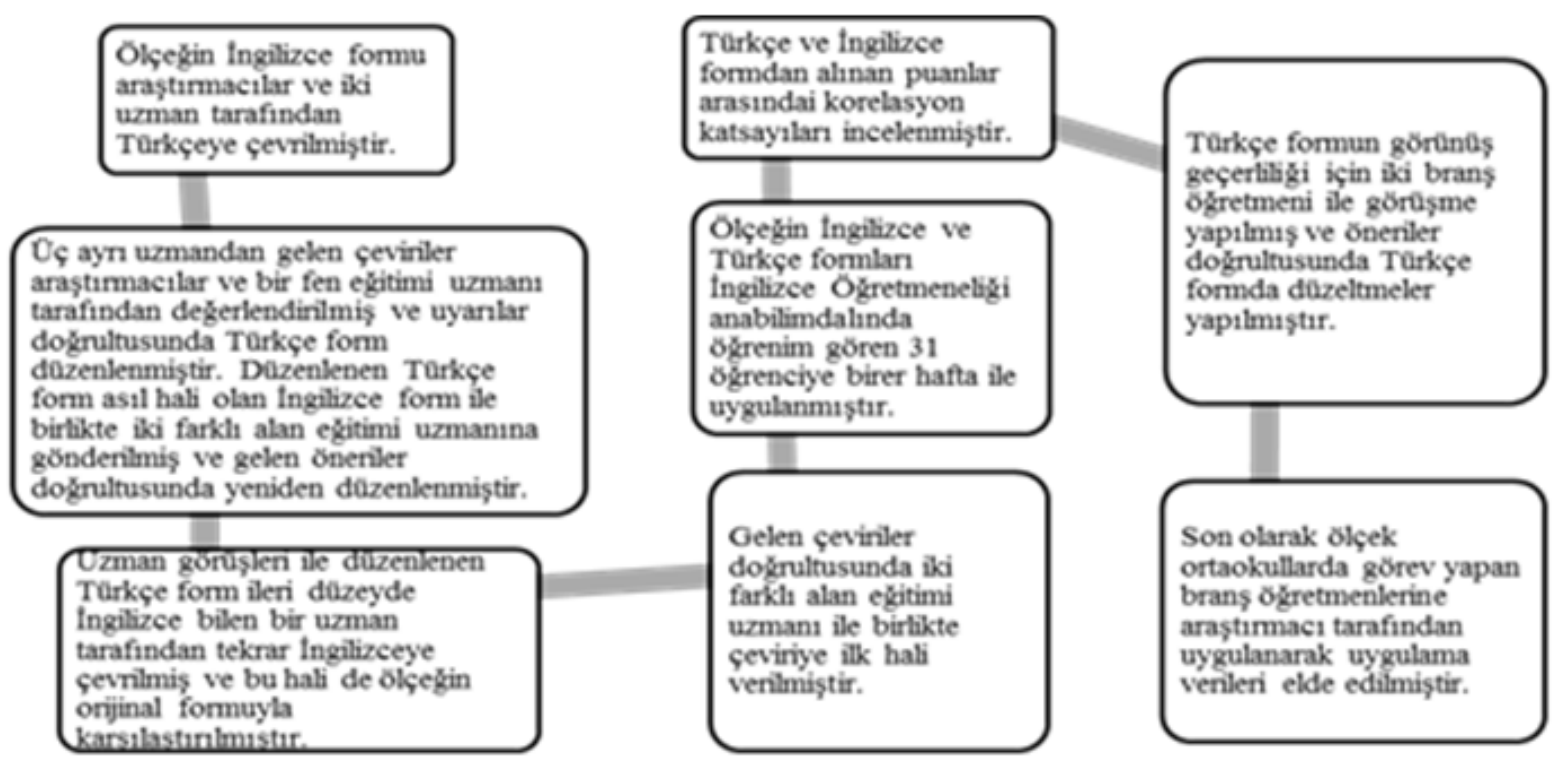

\section{Şekil 1. Ölçek uyarlama aşamasında yürütülen işlemler}

\section{Verilerin Analizi}

Verilerin analizi kapsamında, dil geçerliliği için birer hafta ara ile uygulanan Türkçe ve İngilizce formlardan elde edilen puanlar arasındaki ilişki düzeyi için Pearson Moment Çarpımı Korelasyon katsayısı hesaplanmıştır. Yapı geçerliliği için; doğrulayıcı faktör analizi (DFA), ölçekte yer alan maddelerin güvenilirliği için Cronbach $\alpha$ iç tutarlılık katsayıları hesaplanmıştr. Maddelerin ayırt ediciliklerinin tespitinde ise toplam puana göre belirlenen üst \% 27 ve alt \% $27^{\prime}$ lik grupların ( $n=96)$ madde puanları arasındaki farkın anlamlılığı için t-testi uygulanmıştır.

Ayrıca katılımcıların merkezi sınavlara ilişkin görüşlerinin; cinsiyetlerine, branşlarına ve mesleki kıdemlerine göre farkıılaşıp farklılaşmadığı, çoklu değişken testlerinden MANOVA (çoklu-ANOVA (multivariate ANOVA) esas alınarak incelenmiştir. Bu analizlerde MANOVA esas alınmasının nedeni birden çok bağımlı değişkenin olduğu çalışmalarda, bağımsız örneklem t-testi ve tek yönlü varyans analizi (ANOVA) tekniklerine kıyasla I. tür hata yapma olasılığını düşürmesidir. Bu yolla daha güçlü bir istatistiksel teknik olmasından dolayı varsayımların sağlanması koşuluyla analizlerde MANOVA esas alınmıştır (Pallant, 2007).

\section{Bulgular}

\section{MSYGÖ Geçerlik ve Güvenilirlik Çalışmasına İlişkin Bulgular Dil Geçerliliğine illişkin Bulgular}

Ölçeğin dil geçerliliğini belirleyebilmek amacıyla İngilizce Öğretmenliği Anabilim dalında öğrenim gören 31 öğren- 
ciye birer hafta ile uygulanan Türkçe ve İngilizce formlar arasındaki korelasyon katsayısı .97 olarak tespit edilmiştir. Bu katsayı değeri ölçeğin orijinal formuyla Türkçe formunun dil açısından eş değer olduğunu göstermektedir.

\section{Doğrulayıcı Faktör Analizine (DFA) ilişskin Bulgular}

DFA işlemlerinde, ölçeğin orijinal halindeki iki faktörlü yapı analiz edilmiştir. Faktör yapısının uygunluğu uyum indeksi sonuçlarına göre incelenmiştir. Yapılan birinci düzey doğrulayıcı faktör analizi sonucunda hesaplanan uyum indeksleri ki-kare/serbestlik derecesi (X2/sd); 4.26, uygunluk indeksi (GFI); .90, normlaştrılmamış uygunluk indeksi (NNFI); .90, karşılaştırmalı uygunluk indeksi (CFI); .92, standartlaştırımış ortalama hataların karekökü (SRMR); .09, yaklaşık hataların ortalama karekökü (RMSEA); .10 olarak hesaplanmıştı. Modele ilişkin modifikasyon önerileri doğrultusunda 3. ile 10., 6. ile 9. ve 5. ile 6. maddeler arasında modifikasyon yapılmasına karar verilmiştir. Modifikasyonlar yapılırken modifikasyon yapılan maddelerin aynı alt boyutta olması ve benzer yapıları ölçme özelliklerine dikkat edilmiştir. Yapılan modifikasyonların X2 (Ki-Kare)'ye anlamlı düzeyde katkı sağladığı uyum indeks katsayılarının anlamlı bir şekilde arttğı gözlenmiştir. Modifikasyonlar sonrasında MSYGÖ'nün DFA ile hesaplanan uyum indeksleri ki-kare/serbestlik derecesi (X2/sd); 3.48, uygunluk indeksi (GFI); .93, normlaştırılmamış uygunluk indeksi (NNFI); .92, karşılaştrrmalı uygunluk indeksi (CFI); .94, standartlaştrılmış ortalama hataların karekökü (SRMR); .07, yaklaşık hataların ortalama karekökü (RMSEA); .08 olarak hesaplanmıştir.

Bu uyum indeksleri ile alan yazında kabul edilen değerler karşılaştııldığında bazı uyum indekslerinin iyi (GFI, CFI, $\mathrm{NNFI}, \mathrm{SRMR}$ ) bazılarının ise orta düzeyde $\left(\chi^{2} / s d\right)$ olduğu görülmektedir. Bu uyum indeksleri modelin iyi düzeyde olduğu göstermektedir. Ayrıca analizde her bir madde için elde edilen t değerleri incelendiğinde tüm maddelerin $(p<.01)$ düzeyinde anlamlı olduğu tespit edilmiştir. Bu sonuçlar, modelin verilerle uyumlu olduğunu göstermektedir. MSYGÖ'ye ilişkin madde-örtük değişken ve örtük değişkenler arasındaki standardize edilmiş katsayıları gösteren yol şeması şekil 2'de verilmiştir.

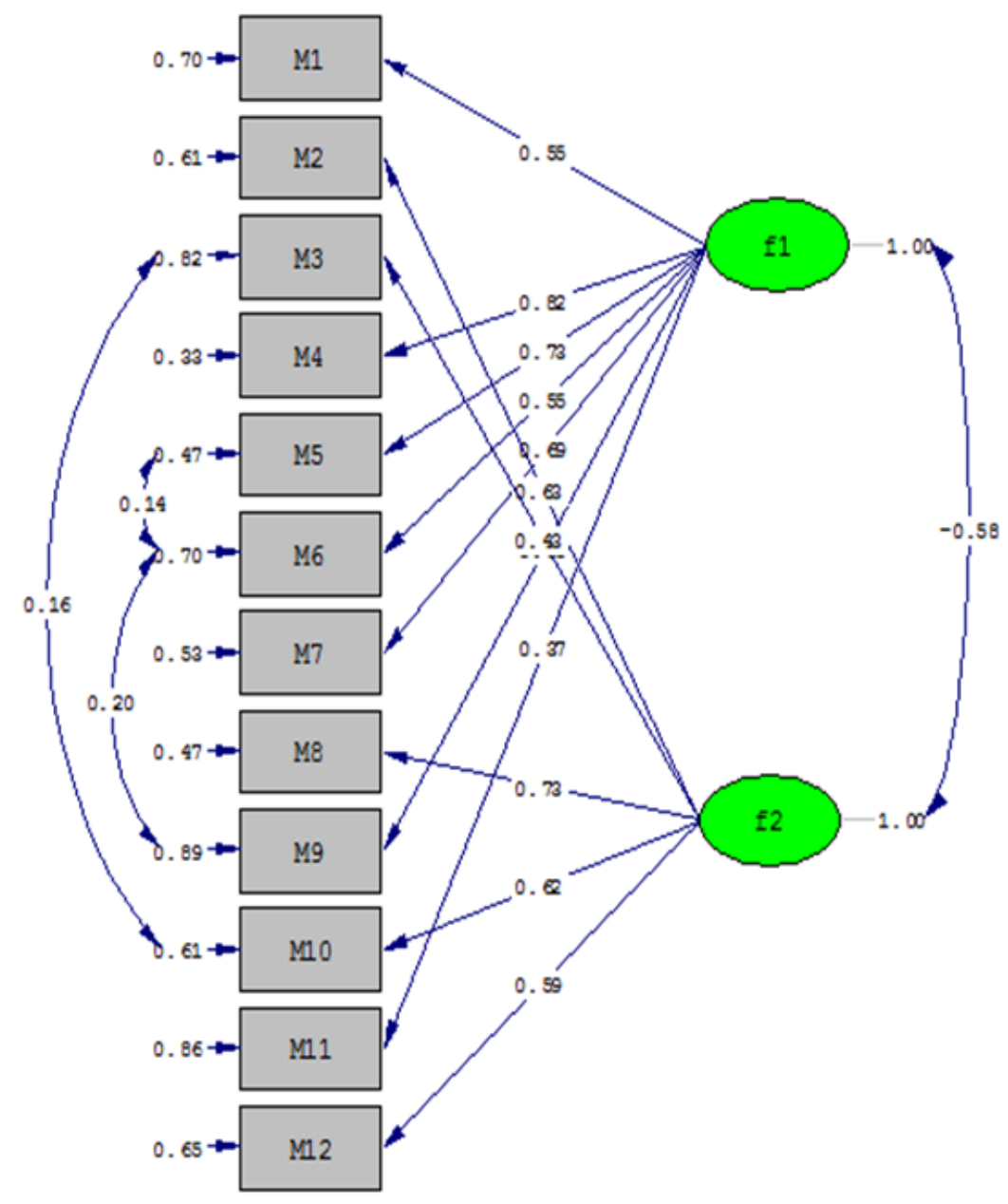

Şekil 2. MSYGÖ’ye ilişkin madde-örtük değişken ve örtük değişkenler arasındaki standardize edilmiş katsayıları gösteren yol şeması 


\section{Maddelerin Ayırt Edicilik Özelliğine İlişkin Bulgular}

MSYGÖ'deki maddeleri ölçtüğü özellik açısından belirlemek ve ayırt edicilik düzeylerini saptamak amacıyla madde analizi yapılmıştır. Bu kapsamda düzeltilmiş madde toplam korelasyonu hesaplanmış üst \% 27 ve alt \% $27^{\prime}$ lik grupların $(n=96)$ puanları arasındaki t-testi sonuçları karşılaştırmalarına yer verilmiştir. Analize ilişkin bulgular Tablo 3'te sunulmuştur.

Tablo 3: MSYGÖ'nün faktörlerinin madde toplam korelasyonları ve üst \% 27 ve alt $\% 27$ 'lik grupların puanları arasındaki t-testi sonuçları

\begin{tabular}{cccccc}
\hline & 1.Faktör (Olumlu görüşler) & \multicolumn{2}{c}{ 2.Faktör (Olumsuz görüşler) } \\
\hline \multirow{2}{*}{ Madde No } & $\begin{array}{c}\text { Madde-toplam } \\
\text { Korelâsyonu }\end{array}$ & $\begin{array}{c}\text { Maddeler için t } \\
\text { (Üst\%27- } \\
\text { Alt \%27) }\end{array}$ & Madde No & $\begin{array}{c}\text { Madde-toplam } \\
\text { Korelâsyonu }\end{array}$ & $\begin{array}{c}\text { Maddeler için t } \\
\text { (Üst \%27-Alt \%27) }\end{array}$ \\
\hline M1 & .47 & $13.04^{*}$ & M2 & .54 & $18.23^{*}$ \\
M4 & .64 & $20.64^{*}$ & M3 & .45 & $11.02^{*}$ \\
M5 & .63 & $24.93^{*}$ & M8 & .58 & $20.90^{*}$ \\
M6 & .57 & $21.02^{*}$ & M10 & .56 & $15.52^{*}$ \\
M7 & .60 & $18.08^{*}$ & M12 & .47 & $18.99 *$ \\
M9 & .39 & $12.20^{*}$ & & & $* p<.01$ \\
M11 & .38 & $11.77^{*}$ & & & \\
\hline
\end{tabular}

Tablo 3'e göre ölçekte yer alan maddelerin madde-toplam korelâsyonlarının .38 ile .64 arasında değiştiği görülmektedir. Üst \% 27 ve alt \% 27'lik grupların madde ortalama puanları arasında yapılan t-testi sonuçlarına göre, farklar tüm maddeler için anlamlıdır. Bu bulgu, ölçekteki tüm maddelerin ayırt edici olduğunu göstermektedir.

\section{Güvenilirliğe İlişkin Bulgular}

MSYGÖ’nün iç tutarlılığı Cronbach $\alpha$ iç tutarlılık katsayıları hesaplanarak incelenmiştir. Ölçek iki faktörden oluştuğundan dolayı Cronbach $\alpha$ iç tutarlıık katsayıları her iki faktör için ayrı ayrı hesaplanmıştır. Buna göre faktörlere ilişkin Cronbach $\alpha$ iç tutarlılık katsayıları Tablo 2'de verilmiştir.

Tablo 2: Merkezi sınavlara yönelik görüşler ölçeğinin faktörlerindeki madde sayıları ve faktörlerin iç tutarlııı katsayıları

\begin{tabular}{lcc}
\hline Faktör ismi & Madde sayısı & Cronbach alfa katsayısı \\
\hline Merkezi sınavlara ilişkin olumlu görüşler & 7 & .79 \\
Merkezi sınavlara ilişkin olumsuz görüşler & 5 & .75 \\
Tüm ölçek & 12 & .80 \\
\hline
\end{tabular}

\section{MSYGÖ Pilot Çalışma Verilerine ilişkin Bulgular}

\section{Merkezi Sınavlara Yönelik Görüşlere ilişskin Bulgular}

Öğretmenlerin merkezi sınavlara yönelik olumlu ve olumsuz görüş faktörlerinden aldıkları puanlar arasında anlamlı bir farklılık olup olmadığının incelenmesi amacıyla yapılan bağımlı örneklemler t-testi sonucunda, öğretmenlerin olumlu görüş puan ortalaması ( $\bar{X}=3.04$ ) ile olumsuz görüş puan ortalaması ( $\bar{X}=2.33$ ) arasında anlamlı bir farklılık olduğu tespit edilmiştir $\left(t_{(355)}=14.04\right.$ < <.01). Test sonucu hesaplanan etki büyüklüğü $(d=.35)$ ve bu farkın geniş etki düzeyinde olduğunu göstermektedir. Söz konusu bu durum araştırmaya katılan öğretmenlerin merkezi sınavlara ilişkin anlamlı olarak daha yüksek düzeyde olumlu görüşlere sahip olduğunu göstermektedir.

\section{Merkezi Sınavlara İlişkin Görüşlerde Cinsiyetler Arasındaki Farklara İlişkin Bulgular}

Öğretmenlerin merkezi sınavlara ilişkin görüşlerinin cinsiyetlerine göre farklılaşıp farkılışmadığını belirlemek amacıyla MANOVA testi kullanılmıştır. MANOVA yapılabilmesi için öncelikle varsayımsal kriterlerin sağlanıp sağlanmadığı incelenmiştir. Yapılan inceleme sonucunda varyansların homojenliği testi sonuçları $(p>.01)$ ve kovaryans matrislerinin eşitliği testi (Box $M$ test=7.41, p>.01) sonucunda varsayımsal kriterlerin sağlandığına karar verilmiştir. Öğretmenlerin merkezi sınavlara yönelik görüşlerine ilişkin puan ortalamalarının cinsiyetlerine göre dağılımı Tablo 4'te gösterilmiştir. 
Tablo 4: Öğretmenlerin merkezi sınavlara yönelik görüşlerine ilişkin puan ortalamalarının cinsiyetlerine göre dağııımı

\begin{tabular}{lccccccccc}
\hline \multirow{2}{*}{ Faktörler } & \multicolumn{3}{c}{ Kadın } & \multicolumn{3}{c}{ Erkek } & \multicolumn{3}{c}{ Toplam } \\
\cline { 2 - 10 } & ort. & ss & $\mathrm{n}$ & ort. & ss & $\mathrm{n}$ & ort. & ss & $\mathrm{n}$ \\
\hline Olumsuz Görüşler & 2.30 & 0.80 & 184 & 2.37 & 0.88 & 172 & 2.33 & 0.84 & 356 \\
Olumlu Görüşler & 3.07 & 0.81 & 184 & 3.01 & 0.76 & 172 & 3.04 & 0.79 & 356 \\
\hline
\end{tabular}

Tablo 4'e bakıldığında merkezi sınavlara yönelik görüşlerin alt faktörlerine göre kadın ve erkek öğretmenlerin puanlarının birbirine oldukça yakın olduğu göze çarpmaktadır. Katılımcıların cinsiyetlerine göre merkezi sınavlara yönelik görüşlerine ait puanlara ilişkin MANOVA testi sonuçlarına göre kadın ve erkek öğretmenlerin merkezi sınavlara yönelik görüşlerinde her iki faktör açısından da anlamlı bir farklılık olmadığı belirlenmiştir (Wilks' Lambda=0.99; $F(2,353)=0.80$; $\mathrm{p}>$.01).

\section{Merkezi Sınavlara İlişkin Görüşlerde Branşlar Arasındaki Farklara İlişkin Bulgular}

Öğretmenlerin merkezi sınavlara ilişkin görüşlerinin branşları açısından farklılaşıp farklılaşmadığını belirlemek amacıyla MANOVA testi kullanılmıştır. MANOVA yapılabilmesi için sağlanması gereken varsayımsal kriterler incelediğinde; varyansların homojenliği testi sonucu ( $p>$. 01) ve kovaryans matrislerinin eşitliği testi sonucunda (Box $M$ test=15.94, p >.01) varsayımsal kriterlerin sağlandığına karar verilmiştir. Öğretmenlerin merkezi sınavlara yönelik görüşlerine ilişkin puan ortalamalarının branşlarına göre dağılımı Tablo 5'de gösterilmiştir.

Tablo 5: Öğretmenlerin merkezi sınavlara yönelik görüşlerine ilişkin puan ortalamalarının branşlarına göre dağılımı

\begin{tabular}{lcccccc}
\hline \multirow{2}{*}{ Branşlar } & \multicolumn{3}{c}{ Olumsuz Görüşler_ } & \multicolumn{3}{c}{ Olumlu Görüşler } \\
\cline { 2 - 7 } & ort. & ss & N & ort. & ss & $\mathrm{n}$ \\
\hline Türkçe & 2.24 & 0.85 & 64 & 2.90 & 0.80 & 64 \\
Matematik & 2.30 & 0.77 & 52 & 3.00 & 0.79 & 52 \\
Fen Bilimleri & 2.43 & 0.77 & 48 & 3.05 & 0.83 & 48 \\
Sosyal Bilgiler & 2.19 & 0.89 & 45 & 3.11 & 0.78 & 45 \\
İngilizce & 2.23 & 0.89 & 53 & 3.12 & 0.78 & 53 \\
Din Kültürü ve Ahlak Bilgisi & 2.29 & 0.80 & 30 & 3.19 & 0.77 & 30 \\
Teknoloji ve Tasarım & 2.40 & 0.90 & 24 & 3.01 & 0.67 & 24 \\
Toplam & 2.29 & 0.83 & 316 & 3.04 & 0.78 & 316 \\
\hline
\end{tabular}

Tablo 5'e bakıldığında merkezi sınavlara yönelik görüşlerin alt faktörlerine göre branşlar açısından öğretmenlerin aldıkları puanlarının birbirine oldukça yakın olduğu göze çarpmaktadır. Ölçeğin olumsuz görüşler alt faktörü için en yüksek puan ortalamasına Fen Bilimleri öğretmenlerinin (2.43) ve en düşük puan ortalamasına ise Sosyal Bilgiler öğretmenlerinin (2.19) sahip olduğu görülmektedir. Ölçeğin olumlu görüşler alt faktörü için en yüksek puan ortalamasına Din Kültürü ve Ahlak Bilgisi öğretmenlerinin (3.19) ve en düşük puan ortalamasına ise Türkçe öğretmenlerinin (2.90) sahip olduğu görülmektedir. Katılımcıların branşlarına göre merkezi sınavlara yönelik görüş puanlarına ilişkin MANOVA testi sonuçlarına göre branşlar açısından öğretmenlerin merkezi sınavlara yönelik görüşlerinde anlamlı bir farklıık olmadığı belirlenmiştir (Wilks' Lambda=0.69; $F(12,616)=0.98 ; p>.01$ ).

\section{Merkezi sınavlara ilişkin görüşlerde mesleki kıdemler arasındaki farklara ilişkin bulgular}

Öğretmenlerin merkezi sınavlara ilişkin görüşlerinin mesleki kıdemlerine göre farklılaşıp farklılaşmadığını belirlemek amacıyla MANOVA testi kullanılmıştır. MANOVA yapılabilmesi için sağlanması gereken varsayımsal kriterler incelediğinde; varyansların homojenliği testi sonucu ( $p>$. 01) ve kovaryans matrislerinin eşitliği testi (Box $M$ test=7.29, $p>.01$ ) sonucunda varsayımsal kriterlerin sağlandığına karar verilmiştir. Öğretmenlerin merkezi sınavlara yönelik görüşlerine ilişkin puan ortalamalarının mesleki kıdemlerine göre dağılımı Tablo 6'da gösterilmiştir.

Tablo 6: Öğretmenlerin merkezi sınavlara yönelik görüşlerine ilişkin puan ortalamalarının mesleki kıdemlerine göre dağılımı

\begin{tabular}{lcccccc}
\hline \multirow{2}{*}{ Mesleki Kıdemler } & \multicolumn{3}{c}{ Olumsuz Görüşler } & \multicolumn{3}{c}{ Olumlu Görüşler } \\
\cline { 2 - 7 } & ort. & ss & $\mathrm{n}$ & ort. & ss & $\mathrm{n}$ \\
\hline $1-5 \mathrm{Y} I \mathrm{l}$ & 2.10 & 0.82 & 69 & 2.88 & 0.80 & 69 \\
$6-10 \mathrm{Y}_{\mathrm{ll}}$ & 2.29 & 0.88 & 99 & 3.12 & 0.77 & 99 \\
\hline
\end{tabular}




\begin{tabular}{|c|c|c|c|c|c|c|}
\hline \multirow{2}{*}{ Mesleki Kıdemler } & \multicolumn{3}{|c|}{ Olumsuz Görüşler } & \multicolumn{3}{|c|}{ Olumlu Görüşler } \\
\hline & ort. & ss & $\mathrm{n}$ & ort. & ss & $\mathrm{n}$ \\
\hline 11-15 Yıl & 2.32 & 0.82 & 96 & 3.03 & 0.78 & 96 \\
\hline 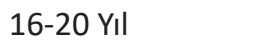 & 2.48 & 0.85 & 54 & 3.03 & 0.79 & 54 \\
\hline 20-üstü Yıl & 2.66 & 0.68 & 30 & 3.14 & 0.81 & 30 \\
\hline Toplam & 2.32 & 0.84 & 348 & 3.04 & 0.78 & 348 \\
\hline
\end{tabular}

Tablo 6’ya bakıldığında mesleki kıdem açısından öğretmenlerin merkezi sınavlara yönelik görüş puanlarının 1-5 yıl kıdem yılına sahip öğretmenler haricinde birbirine oldukça yakın olduğu göze çarpmaktadır. Ölçeğin olumsuz görüşler alt faktörü için en yüksek puan ortalamasının 20 yıl ve üstü mesleki kıdeme sahip öğretmenlerin (2.66) ve en düşük puan ortalamanın ise 1-5 yıl mesleki kıdeme sahip öğretmenlerin (2.10) olduğu görülmektedir. Benzer şekilde ölçeğin olumlu görüşler alt faktörü için de en yüksek puan ortalamasının 20 yıl ve üstü mesleki kıdeme sahip öğretmenlerin (3.14) ve en düşük puan ortalamanın ise 1-5 yıl mesleki kıdeme sahip öğretmenlerin (2.88) olduğu görülmektedir. Katılımcıların mesleki kıdemlerine göre merkezi sınavlara yönelik görüş puanlarına ilişkin MANOVA testi sonuçlarına göre mesleki kıdeme göre merkezi sınavlara yönelik görüşler alt faktörleri puanları arasında anlamlı bir farklılık olmadığı belirlenmiştir (Wilks' Lambda=1.81; $F(8,684)=0.96$ p >.01).

\section{Tartışma, Sonuç ve Öneriler}

Bu çalışma kapsamında ortaokul öğretmenlerinin merkezi sınavlar hakkındaki görüşlerini belirlemek amacıyla Genç (2005) tarafindan geliştirilen "Merkezi Sınavlara Yönelik Görüşler" ölçeğinin Türkçeye uyarlama ve geçerlik güvenirlik çalışması yapılmıştr. Ölçeğin Türkçe formunun geçerliğini tespit etmek amacıyla; dil geçerliği ve yapı geçerliği incelenmiş ayrıca maddelerin ayırt edicilik özellikleri belirlenmiş ve ölçeğin faktörleri arasındaki korelasyonlar katsayıları tespit edilmiştir. Ölçeğin güvenilirlik koşullarını sağlayıp sağlayamadığının belirlenmesi için ise ölçekte yer alan faktörlerin iç tutarlıık katsayıları Cronbach $\alpha$ katsayı değeriyle hesaplanmıştı. Sonuç olarak ölçeğin Türkçe formunun'da orijinal halinde olduğu gibi 12 maddeden ve iki faktörden meydana geldiği tespit edilmiştir. Buna göre 7 maddelik ilk faktör "Merkezi sınavlara ilişkin olumlu görüşler" ve 5 maddelik ikinci faktör "Merkezi sınavlara ilişkin olumsuz görüşler" olarak adlandırılmıştır.

Çalışmada ele alınan ikinci araştırma problemi kapsamında ölçekten elde edilen pilot çalışma verileri kullanılarak ortaokul öğretmenlerinin merkezi sınavlara yönelik görüşleri belirlenmiş ve öğretmenlerin merkezi sınavlara yönelik olumlu ve olumsuz görüşleri arasında anlamlı bir farklılık olup olmadığını incelenmiştir. Araştırmada elde edilen bulgulara göre ortaokul öğretmenlerinin merkezi sınavlara yönelik hem olumlu hem de olumsuz görüşlere sahip oldukları ancak olumlu görüşlerinin anlamlı olarak olumsuz görüşlerden yüksek düzeyde olduğu belirlenmiştir. Bu sonuçla paralel olarak alan yazında daha önce yapılan çalışmalarda elde edilen sonuçlara göre de öğretmenlerin merkezi sınavlara ilişkin bazı olumlu ve olumsuz görüşlere sahip oldukları bilinmektedir. Örneğin merkezi sınavlara ilişkin olumlu görüşler arasında; merkezi sınavların ölçme ve değerlendirmede bir standart sağlaması (Afflerbach, 2004; Genç, 2005), öğrencilerin çalışmaya yönelik motivasyonlarını artırması (Elmore, 2004; Herman, 2004; Kahraman, 2014), öğrencilerin içinde bulundukları toplum standartlarına göre başarılarını ortaya koyması ve başarıların karşılaştrıımasını sağlaması (Jones vd. 2003; Kahraman, 2014; Pedulla vd. 2003) gibi görüşler yer almaktadır. Benzer şekilde merkezi sınavlara ilişkin olumsuz görüşler arasında ise; bu sınavların öğretmenleri baskı altnnda tutması ve strese neden olması (Buldur, 2014; Buyruk, 2014; Genç, 2005; Dawson, 2012; Moses ve Nanna, 2007), öğretim programının uygulanmasının önünde engel teşkil etmesi (Jones vd. 2003; McMillan vd. 1999; Smyth, 2008) ve öğretmenlerin iş yükünü artırması (Moses ve Nanna, 2007) gibi görüşler örnek verilebilir.

Sonuç olarak araştırmada elde edilen bulgulara göre ortaokul öğretmenlerinin merkezi sınavlara yönelik olumlu görüşlerinin anlamlı olarak olumsuz görüşlerden yüksek düzeyde olduğu belirlenmiştir. Ancak bulgular katlımcıların merkezi sınavlara yönelik olumsuz görüşlerinin de ortalamanın sadece biraz altında olduğunu göstermektedir. Bu bulgu öğretmenlerin merkezi sınavlara yönelik olumlu görüşlerinin yüksek olmasının yanında olumsuz görüşlere de sahip olduklarını göstermektedir. Bu bulgular alan yazında yapılan çalışmalarda elde edilen öğretmenlerin merkezi sınavlara ilişkin hem olumlu hem de olumsuz görüşlere sahip olmaları sonucuyla paralellik taşımaktadır.

Araştırmada ele alınan üçüncü araştırma probleminde öğretmenlerin merkezi sınavlara yönelik görüşlerinin cinsiyet, branş ve mesleki kıdem değişkenlerine göre farklılık olup olmadığını incelenmiştir. Araştırma sonucunda elde edilen bulgular öğretmenlerin merkezi sınavlara yönelik görüşlerinin cinsiyet, branş ve mesleki kıdemlerine göre farklılaşmadığını göstermiştir. Benzer öğretmen yetiştirme sisteminden gelen ve benzer şartlarda görev yapan öğretmenlerin merkezi sınavlara yönelik görüşlerinde bahsi geçen demografik değişkenler açısından fark görülmemesi beklenen bir 
sonuçtur. Öğretmenlerin merkezi sınavlara yönelik görüşlerinin incelendiği benzer çalışmaların bazılarında bu çalışma sonuçlarına paralel olarak cinsiyet açısından bir farklılık olmadığı tespit edilirken (Brockmeier vd. 2014; Green ve Stager, 1987; Osborn, 2015) bazı araştırmalarda (Cormany, 1974) ise cinsiyet açısından anlamlı farklar tespit edilmiştir. Araştırma sonucunda öğretmenlerin merkezi sınavlara yönelik görüşlerinin mesleki kıdemlerine göre farklılaşmadığı sonucu da Osborn'in (2015) çalışmasında elde edilen sonuçla paralellik göstermektedir.

Araştırmada elde edilen sonuçlar bir ilin merkez ortaokullarında görev yapan 356 branş öğretmeninden elde edilen verilerle sınırlıdır. Bu örneklemin Türkiye'deki bütün ortaokul branş öğretmenlerini temsil etmesi beklenemez; ancak örnekleme alınan öğretmenlerin Milli Eğitim Bakanlığına bağlı tüm ortaokullarda aynı öğretim programlarını kullandıkları ve genel olarak benzer öğretmen yetiştirme sistemlerinden yetişerek benzer şartlarda çalıştkları göz önüne alındığında örnekleme alınan öğretmenlerin diğer meslektaşları ile benzer karakteristik ve akademik özelliklere sahip oldukları varsayılabilir. Bu nedenle bu çalışma sonucunda elde edilen sonuçların özellikle benzer bölgedeki ortaokullarda görev yapan öğretmenler için genellenebileceği söylenebilir. Ancak yine de bu sınırlıı̆ın üstesinden gelebilmek amacıyla tüm ortaokul branş öğretmenleri evrenini temsil edebilecek daha genişörneklemler üzerinde çalışmalar yapılması önerilebilir. Ancak bu yolla bu çalışmada örneklem seçimi ile ilgili karşılaşılan sınırlıı̆ın üstesinden gelinebileceği düşünülmektedir.

Yapılan bu çalışmada öğretmenlerin merkezi sınavlara yönelik görüşleri, cinsiyet, branş ve mesleki kıdem değişkenleri ile sınırlandırılmıştı. Yeni araştırmalarda farklı demografik değişkenlerin incelenmesi önerilebilir. Bu çalışmada öğretmenlerin merkezi sınavlara yönelik görüşleri bir ölçek aracılığıyla belirlenmiştir. Yeni çalışmalarda bu konuda daha derinlemesine bir anlayış geliştirmek için görüşme ve gözlem gibi nitel veri toplama yöntemleri kullanılarak yürütülecek farklı desenlerdeki araştırmalar yapılması önerilebilir. Bu araştırmada öğretmenlerin genel olarak merkezi sınavlara yönelik görüşlerinin belirlenebileceği bir ölçek alan yazına kazandırılmıştır. Bu sayede öğretmenlerin merkezi sınavlara yönelik görüşlerinin araştrılacağı farklı çalışmalarda bu ölçeğin kullanılması önerilmektedir. Ortaokul branş öğretmenleri örnekleminde uyarlanan bu ölçek rahatılıkla diğer düzeylerde görev yapan öğretmenler içinde kullanılabilecektir.

\section{Kaynakça}

Abadiano, H.R. \& Turner, J. (2003). Thinking it through: Re-examining our beliefs about assessment for diverse students. NERA Journal, 39(1), 58-63.

Abrams, L., Pedulla, J. \& Madaus, G. F. (2003). Views from the classroom: Teachers' opinions of statewide testing programs. Theory into Practice, 42(1), 18-29.

Afflerbach, P. (2005). High stakes testing and reading assessment. National reading conference policy brief. Journal of Literacy Research, 37(2), 151-162.

Amrein, A. L., \& Berliner, D. C. (2002a). An analysis of some unintended and negative consequences of high-stakes testing. Retrieved from https://nepc.colorado.edu/sites/default/files/EPSL-0211-125-EPRU.pdf

Bol, L. (2004). Teachers' assessment practices in a high-stakes testing environment. Teacher Education and Practice, 17(2), $162-181$.

Brockmeier, L. L., Green, R. B., Pate, J. L., Tsemunhu, R., \& Bockenko, M. J. (2014). Teachers' beliefs about the effects of high stakes testing. Journal of Education and Human Development, 3(4), 91-104.

Buldur, S. (2014). Performansa dayalı tekniklerle yürütülen biçimlendirmeye yönelik değerlendirme sürecinin öğretmen ve öğrenci üzerindeki etkisi. Yayımlanmamış Doktora Tezi, Gazi Üniversitesi Eğitim Bilimleri Enstitüsü, Ankara.

Buldur, S., \& Doğan, A. (2017). Performansa dayalı tekniklerle yürütülen biçimlendirmeye yönelik değerlendirme sürecinin öğrencilerin hedef yönelimlerine etkisi. Hacettepe Üniversitesi Eğitim Fakültesi Dergisi, 32(1), 143-167.

Buyruk, H. (2014). Öğretmen performansının göstergesi olarak merkezi sınavlar ve eğitimde performans değerlendirme. Trakya Üniversitesi Eğitim Fakültesi Dergisi, 4(2), 28-42.

Calveric, S. B. (2010). Elementary teachers' assessment beliefs and practices. Unpublished Doctoral Dissertation, Virginia Commonwealth University, USA.

Cormany, R. B. (1974). Faculty attitudes toward standardized testing. Measurement and Evaluation in Guidance, 7, 188-194.

Dawson, H.S. (2012). Teachers' motivation and beliefs in a high-stakes testing context. Unpublished Doctoral Dissertation. The Ohio State University.

Dinç, E., Dere, İ. ve Koluman, S. (2014). Kademeler arası geçiş uygulamalarına yönelik görüşler ve deneyimler. Adıyaman Üniversitesi Sosyal Bilimler Enstitüsü Dergisi, 7(17), 397-423.

Elmore, R.F. (2004). Conclusion: The problem of stakes in performance-based accountability systems. In S.H. Furhman and R.F. Elmore (Eds), Redesigning Accountability Systems for Education (pp. 274-296). New York, NY: Teachers College Press. 
Flowers, C., Ahlgrim-Delzell, D., Browder, D. \& Spooner, F. (2005). Teachers' perceptions of alternate assessments. Research and Practice for Persons with Severe Disabilities, 30(2). 81-92.

Furhman, S.H. (2004). Introduction. In S.H. Furhman \& R.F. Elmore (Eds), Redesigning accountability systems for education (pp. 3-14). New York, NY: Teachers College Press.

Genç, E. (2005). Development and validation of an instrument to evaluate science teachers' assessment beliefs and practice. Unpublished Doctoral Dissertation, College of Education, the Florida State University.

Gilligan, M.E. (2007). Traditional versus alternative assessments: which type do high school teachers perceive as most effective in the assessment of higher-order thinking skills. Unpublished Doctoral Dissertation, Saint Louis University.

Green, K. E. \& Stager, S. F. (1987). Testing, coursework, attitudes, and practices. Educational Research Quarterly, 11(2), $48-55$.

Greene, C.C. (2011). Third grade teachers' experiences in preparing for and interacting with the Ohio achievement assessment: A hermeneutic phenomenological study of the effects of the 2001 no child left behind act. Unpublished Doctoral Dissertation, Kent State University.

Gündoğdu, K., Kızıltaş, E. ve Çimen, N. (2010). Seviye belirleme sınavına (SBS) ilişkin öğrenci ve öğretmen görüşleri (Erzurum il örneği). ilköğretim Online, 9(1), 316-330.

Herman, J. (2004). The effects of testing on instruction. In S.H. Furhman \& R.F. Elmore (Eds), Redesigning Accountability Systems for Education (pp. 141-166). New York, NY: Teachers College Press.

Hilliard, A.G. (2000). Excellence in education versus high-stakes standardized testing. Journal of Teacher Education, 51(4), $293-304$.

Jones, B. D. \& Egley, R. J. (2004). Voices from the frontlines: Teachers' perceptions of high-stakes testing. Education Policy Analysis Archives, 12(39),1-34.

Jones, G. M., Jones, B. D., \& Hargrove, T. (2003). The unintended consequences of high-stakes testing. Rowman \& Littlefield Publishers.

Kahraman, I. (2014). Merkezi ortak sınav uygulamasının etkilerine ilişkin öğretmen görüşleri. Tunceli Üniversitesi Sosyal Bilimler Dergisi, 2 (4), 53-74.

McMillan, J. H., Myran, S. \& Workman, D. (1999). The impact of mandated statewide testing on teachers' classroom assessment and instruction practices. Retrieved from https://files.eric.ed.gov/fulltext/ED431041.pdf

McWaters, J.K. (2001). An exploratory study of the influence of national and state standards on middle school science teachers' classroom assessment practices. Unpublished Doctoral Dissertation, LSU Historical Dissertations and Theses.

Moses, M. S. \& Nanna, M. J. (2007). The testing culture and the persistence of high stakes testing reforms. Education and Culture, 23(1), 55-72.

Olsen, B. \& Sexton, D. (2008). Threat rigidity, school reform, and how teachers view their work inside current education policy contexts. American Educational Research Journal, 46, 9-44.

Osborn, R. L. (2015). Teacher and administrator perceptions of high stakes testing. Unpublished Doctoral Dissertation, University of West Georgia.

Özkan, M. ve Benli Özdemir, E. (2014). Ortaokul 8. sınıf öğrencilerinin ve öğretmenlerinin ortaöğretime geçişte uygulanan merkezi ortak sınavlara ilişkin görüşleri. Tarih Okulu Dergisi (TOD), 7(10), 441-453.

Pallant, J. (2007). SPSS survival manual. New York, NY: Mc Graw Hill.

Paris, S.G. \& Urdan, T. (2000). Policies and practices of high-stakes testing that influence teachers and schools. Issues in Education 6(1/2), 83-108.

Pedulla, J.J, Abrams, M. L., Madaus, G.F., Russell, M.K., Ramos, A.M., \& Miao, J. (2003). Perceived effects of state-mandated testing programs on teaching and learning: Findings from a national survey of teachers. Retrieved from https://files.eric.ed.gov/fulltext/ ED481836.pdf

Schulz, B.C. (2005). Teachers' perspectives of how high-stakes testing influences instructional decisions and professionalism. Unpublished Doctoral Dissertation, The University of Georgia.

Sikka, A., Nath, J. L. \& Cohen, M. D. (2007). Practicing teachers' beliefs and uses of assessment. International Journal of Case Method Research and Application, 19(3), 240-253.

Smyth, T. S. (2008). Who is no child left behind leaving behind? The Clearing House: A Journal of Educational Strategies, Issues and Ideas, 81(3), 133-137.

Şad, S. N. ve Şahiner, Y. K. (2016). Temel eğitimden ortaöğretime geçiş (TEOG) sistemine ilişkin öğrenci, öğretmen ve veli görüşleri. illköğretim Online, 15(1), 53-76.

Şeker, H. ve Gençdoğan, B. (2006). Psikolojide ve eğitimde ölçme aracı geliştirme. Ankara: Nobel Yayıncılık.

Watt, H. M. G. (2005). Attitudes to the use of alternative assessment methods in mathematics: a study with secondary mathematics teachers in Sydney, Australia. Educational Studies in Mathematics, 58(1), 21-44. 